\title{
Editorial
}

\section{Adenoma Detection Rate: Quality Indicators for Colonoscopy}

\author{
Teresa Pinto-Pais \\ Gastroenterology Department, Instituto Português de Oncologia do Porto Francisco Gentil, Porto, Portugal
}

Keywords

Adenoma detection rate $\cdot$ Colonoscopy $\cdot$ Colorectal cancer

\section{Taxa de Deteção de Adenomas: Indicador de Qualidade em Colonoscopia}

\section{Palavras Chave}

Taxa de deteção de adeomas · Colonoscopia .

Cancro colorrectal

Colorectal cancer (CRC) is the second most common tumor in women and the third most common in men and accounts for $10 \%$ of all types of tumors worldwide. In Portugal, CCR is the first cause of cancer and cancer-related mortality [1].

Screening programs for CRC are currently implemented in many western populations $[2,3]$ because randomized trials have documented an association between screening and a sustained reduction in colorectal cancer mortality [4]. The benefit is most likely due to early detection of cancer, endoscopic removal of adenomas, and surveillance of patients who are considered to be at a high risk for the development of new neoplastic lesions $[5,6]$.

\section{KARGER}

E-Mail karger@karger.com www.karger.com/pjg
(C) 2017 Sociedade Portuguesa de Gastrenterologia Published by S. Karger AG, Basel

Karcer

Open access

This article is licensed under the Creative Commons AttributionNonCommercial-NoDerivatives 4.0 International License (CC BYNC-ND) (http://www.karger.com/Services/OpenAccessLicense). Usage and distribution for commercial purposes as well as any distribution of modified material requires written permission.
There is considerable evidence that adenomatous polyps amenable to endoscopic resection predate cancer, and that polypectomy reduces the likelihood of cancer [7]. Therefore, colonoscopy is now the gold standard for CRC screening $[8,9]$ as it allows for the detection and removal of premalignant lesions. However, the effectiveness of colonoscopy is strongly associated with its quality.

Among different quality indicators, the one most used is the adenoma detection rate (ADR), which is the percentage of average-risk patients for CRC who are found to have at least 1 adenoma or adenocarcinoma during a screening colonoscopy. There is compelling evidence supporting an inverse correlation between ADR and interval CRC (cancer found after a screening colonoscopy) [10], which will lower future mortality from CRC. For this reason, $\mathrm{ADR}$ is increasingly being used to assess the quality of colonoscopy.

In fact, quality measures can be used to maximize the effectiveness of colonoscopy by guiding consistent, highquality practice. As defined by the Center for Medicare and Medicaid Services, quality measures are tools that help us measure or quantify health-care processes that are associated with the ability to provide high-quality health care and/or that relate to one or more quality goals for health care [11]. Quality measures are increasingly being used for reimbursement for colonoscopy and may also 
affect patient utilization. A recent survey from Solad et al. [12] of 417 patients found that $20 \%$ researched their endoscopist's rating.

The European Society of Gastrointestinal Endoscopy (ESGE) [13] and the American Society of Gastrointestinal Endoscopy (ASGE) ${ }^{\mathrm{RED}}$ [9] published a set of indicators and the recommended quality thresholds to ensure effective screening. Many factors such as quality of precolonoscopy preparation, additional observers, maneuvers with the endoscope (second view, retroflexion, water inflation rather than air), time spent during withdrawal, changes in patient position, fold-flattener devices, new imaging or endoscopic modalities, and use of intravenous or throughthe-scope sprayed drugs, have been studied and developed with the aim of increasing the ADR. ADR, the primary quality indicator or outcome for an endoscopist, can be viewed as a function of the other quality measures [14].

The ASGE/American College of Gastroenterology (ACG) Task Force on Quality in Endoscopy suggests that all endoscopists performing colonoscopy should measure the quality of their colonoscopy [15]. Moreover, it is recommended that institutions where endoscopists from multiple specialties are practicing should reasonably expect all endoscopists to participate in the program and achieve recommended quality benchmarks.
In this issue, a retrospective study by Oliveira Ferreira et al. [16] entitled "Adenoma Detection Rate: I Will Show You Mine If You Show Me Yours" is published. The authors retrospectively analyzed the colonoscopy quality of their endoscopy unit, which included 654 screening procedures from a total of 5,860 colonoscopies performed in 3 years. Interestingly, the authors found an ADR of $36 \%$ (95\% CI 32-39), which is above the current quality threshold of $25 \%$ set by the endoscopic societies [9]. Although $83 \%$ of the patients had a positive fecal occult blood test as the indication for colonoscopy, the ADR in both the screening and fecal occult blood test groups was remarkably similar, and the estimated confidence intervals were above $25 \%$ in both groups. With this internal audit, the authors aim to implement a proven strategy to improve bowel preparation quality and also emphasize that quality assessment should be mandatory in all endoscopy units. The ultimate goal of this article is to increase the public acceptance of colonoscopy by showing data to support its' effectiveness and decrease the incidence and CRC-associated mortality in Portugal.

This retrospective work emphasizes colonoscopy quality assurance/improvement and discusses current evidence to improve patient care and optimize ADR.

\section{References}

1 Ferlay J, Soerjomataram I, Dikshit R, Eser S, Mathers C, Rebelo M, et al: Cancer incidence and mortality worldwide: sources, methods and major patterns in GLOBOCAN 2012. Int J Cancer 2015; 136:E359-E386.

2 Bretthauer M, Kalager M: Colonoscopy as a triage screening test. N Engl J Med 2012;366: 759-760.

3 Garborg K, Holme Ø, Løberg M, Kalager M, Adami HO, Bretthauer M: Current status of screening for colorectal cancer. Ann Oncol 2013;24:1963-1972.

4 Shaukat A, Mongin SJ, Geisser MS, Lederle FA, Bond JH, Mandel JS, Church TR: Longterm mortality after screening for colorectal cancer. N Engl J Med 2013;369:1106-1114.

5 Nishihara R, Wu K, Lochhead P, Morikawa T, Liao X, Qian ZR, et al: Longterm colorectalcancer incidence and mortality after lower endoscopy. N Engl J Med 2013;369:1095-1105.

6 Zauber AG, Winawer SJ, O’Brien MJ, Lansdorp-Vogelaar I, van Ballegooijen M, Hankey $\mathrm{BF}$, et al: Colonoscopic polypectomy and long-term prevention of colorectal-cancer deaths. N Engl J Med 2012;366:687-696.
7 Winawer SJ, Zauber AG, Ho MN, O’Brien MJ, Gottlieb LS, Sternberg SS, et al: Prevention of colorectal cancer by colonoscopic polypectomy. The National Polyp Study Workgroup. N Engl J Med 1993;329:1977-1981.

8 Qaseem A, Denberg TD, Hopkins RH Jr, Humphrey LL, Levine J, Sweet DE, Shekelle P: Screening for colorectal cancer: a guidance statement from the American College of Physicians. Ann Intern Med 2012;156:378-386.

9 Rex DK, Johnson DA, Anderson JC, Schoenfeld PS, Burke CA, Inadomi JM: American College of Gastroenterology guidelines for colorectal cancer screening 2009. Am J Gastroenterol 2009;104:739-750.

10 Kaminski MF, Regula J, Kraszewska E, Polkowski M, Wojciechowska U, Didkowska $\mathrm{J}$, et al: Quality indicators for colonoscopy and the risk of interval cancer. N Engl J Med 2010; 362:1795-1803.

11 Centers for Medicare \& Medicaid Services: Quality measures. http://www.cms.gov/ Medicare/Quality-Initiatives-Patient-Assessment-Instruments/QualityMeasures/index. html?redirect=/QUALITYMEASURES/ (accessed December 21, 2015).
12 Solad Y, Wang C, Laine L, Deng Y, Schwartz $\mathrm{H}$, Ciarleglio MM, Aslanian HR: Influence of colonoscopy quality measures on patients' colonoscopist selection. Am J Gastroenterol 2014;110:215-219.

13 Rembacken B, Hassan C, Riemann JF, Chilton A, Rutter M, Dumonceau JM, et al: Quality in screening colonoscopy: position statement of the European Society of Gastrointestinal Endoscopy (ESGE). Endoscopy 2012;44: 957-968.

14 Jover R, Zapater P, Polanía E, Bujanda L, Lanas A, Hermo JA, et al: Modifiable endoscopic factors that influence the adenoma detection rate in colorectal cancer screening colonoscopies. Gastrointest Endosc 2013;77: 381-389.

15 Rex DK, Schoenfeld PS, Cohen J, Pike IM, Adler DG, Fennerty MB, et al: Quality indicators for colonoscopy. Gastrointest Endosc 2015;81:31-53.

16 Ferreira AO, Fidalgo C, Palmela C, Santos MP, Torres S, Nunes J, Loureiro R, Ferreira R, et al: Adenoma detection rate: I will show you mine if you show me yours. GE Port J Gastroenterol 2017, DOI: 10.1159/000450901. 